\title{
The potential of the Phytotoxkit microbiotest for hazard evaluation of sediments in eutrophic freshwater ecosystems
}

\author{
Izabela Czerniawska-Kusza • G. Kusza
}

Received: 15 November 2009 / Accepted: 20 September 2010 / Published online: 5 October 2010

(C) The Author(s) 2010. This article is published with open access at Springerlink.com

\begin{abstract}
The applicability of the Phytotoxkit microbiotest for toxicity assessment of sediments in eutrophic freshwater ecosystems was evaluated. Sediments were collected from Turawa dam reservoir (southwestern Poland) which, for years, has been subjected to a marked nutrient enrichment and heavy metal contamination. The test plant species were exposed to whole sediments, solid phases of sediments, and pore waters. Phytotoxicity was estimated on the basis of seed germination and root elongation measurements, combined into an overall germination index (GI). For pore waters, the majority of GI values were not statistically different from the controls, which was consistent with chemical data. For solid phases and whole sediments, GI values showed diversified effects ranging from growth stimulation to growth inhibition. The results obtained vary depending on the plant species and the type of sediment samples. Generally, tests with solid phases of sediments showed phytostimulation, suggesting that higher amount of nutrients adsorbed on organic matterrich sediments might conceal the inhibitory impact of heavy metals $(\mathrm{Cd}, \mathrm{Cr}, \mathrm{Cu}, \mathrm{Mn}, \mathrm{Ni}, \mathrm{Pb}$, and
\end{abstract}

I. Czerniawska-Kusza ( $\varangle) \cdot$ G. Kusza

Department of Land Protection, University of Opole,

Oleska 22, 45-050 Opole, Poland

e-mail: Izabela.Kusza@uni.opole.pl
$\mathrm{Zn})$. However, this beneficial impact is indicative of a significant nutrient load and, with respect to aquatic ecosystems, its potential resuspention that might accelerate the reservoir eutrophication. Under appropriate conditions heavy metals exerted stronger negative impact on plants. Tests with whole sediments had a higher acidity (pH 5.85) and showed adverse effects, though plant responses vary from inhibition (Lepidium sativum) to stimulation (Sorghum saccharatum). The study demonstrated variability in toxicity of contaminated nutrient-rich sediments as well as effectiveness and usefulness of the Phytotoxkit microbiotest as a practical and reliable tool for evaluation of the hazard of eutrophic ecosystems to higher plants.

Keywords Nutrient-rich sediments • Heavy metals $\cdot$ Phytotoxicity $\cdot$ Microbiotest

\section{Introduction}

The increased role of various human activities in the environmental pollution has intensified the studies on integrated effects of natural and anthropogenic factors on living organisms as well as the search for a suitable low-cost tool for environmental risk evaluation. To estimate the pollution risk and to better comprehend the negative impact that chemical agents can have on biological 
integrity, chemical methods need to be complemented with biological and ecotoxicological ones (Chapman 1990; McCauley et al. 2000). Furthermore, for assessing contaminants potentially hazardous to the environment, ecotoxicological testing should include organisms of different trophic levels, representing both environmental media, i.e., terrestrial and aquatic (Cheung et al. 1997; Garcia-Lorenzo et al. 2009). The above factors have prompted the development and application of microbiotests. Due to their short-exposure periods and their relatively high sensitivity, microbiotests have been successfully used as adequate tools for screening and ranking of the hazards of chemicals and environmental wastes, hence they contribute to a reliable risk assessment for water and soil environments (Persoone et al. 2000).

Although plants as the primary food producers are an essential part of balanced ecosystem, the use of vascular plants to assess environmental risk has only gained attention in recent decades. Higher plant phytotoxicity bioassays, based on seed germination, root elongation, and early seedling growth measurements, have been conducted with various terrestrial and aquatic plant species (Wang 1991; Mohan and Hosetti 1999). Up to now, data on phytotoxicity studies have been considered in the toxicity evaluation of various media, such as commercial chemicals (Günter and Pestemer 1990), industrial and municipal effluents, hazardous wastes, leachates (Vasseur et al. 1998; Wang and Williams 1988; Filidei et al. 2003), and contaminated soils and sediments (Beltrami et al. 1999; Valerio et al. 2007). Recently, phytotoxicity test with terrestrial plants are receiving increasing attention also in assessing sediment toxicity, particularly in terms of dredging activity (Chen et al. 2002). Sediments in natural ecosystems are formed by sedimentation of particles from the overlying water column. During this process, adsorption to suspended particulate matter as well as precipitation processes rapidly transfer both contaminants and nutrients from surface waters to bottom sediments, leading to their accumulation. Although most adsorbed pollutants are not readily available for aquatic organisms, sediments may become an important pollution source, depending on environmental conditions (temperature, $\mathrm{pH}$, redox, and the content of or- ganic chelates, among others) (Salomons et al. 1987). Therefore, displacement of sediments (e.g., dredging, deposition, and decontamination) is a major source of concern for aquatic ecosystems because it may cause mobilization and resuspension of contaminants with potential consequences on aquatic biota and water quality. With regard to aquatic and terrestrial plant species, it is apparent that higher plants and algae complement each other as toxicity test species when exposed to variety of toxicants (Chung et al. 2007). Though plants provide evidence of the toxic effects of contaminated soils/sediments, their response is also affected by nutrient conditions (Nakamura et al. 2002). Due to this, as well as to a recovery ability of mitotic activity in the primary root meristem (Wierzbicka 1994), some evidence for phytostimulation of contaminated sediments have been reported (Devesa-Rey et al. 2008).

The objective of the present study was to assess (1) the contamination of sediments in the eutrophic dam reservoir of Turawa and (2) the potential phytotoxic effect of contaminated sediments. In order to look for a cause and effect relationship for plants, seeds were exposed to sediment samples rich in both nutrients (stimulating factors) and heavy metals (inhibitory factors). The study provides the assessment of phytotoxicity using the Phytotoxkit microbiotest (Phytotoxkit 2004) and different fractions of sediment samples, which might have an influence on sediment parameters during the test procedure.

\section{Materials and methods}

Study area and sediment collection

The study was conducted on sediments collected from the dam reservoir of Turawa, built in the lower course of the Maşa Panew River (southwestern Poland). The reservoir has been functioning since 1948. Its basic morphometric and hydrological parameters are as follows: mean water table surface-1,966 ha, mean capacity$92.5 \mathrm{mln} \mathrm{m}^{3}$, mean depth-5.1 m, length-7,500 m, width-from 2,500 to $4,000 \mathrm{~m}$, water retention time-151 days, mean water discharge$7.06 \mathrm{~m}^{3} \mathrm{~s}^{-1}$, and drainage basin $-1.424 \mathrm{~km}^{2}$. 
Similarly to other lowland reservoirs, Turawa one has been subjected to marked nutrient enrichment. This results from the high ratio of the reservoir basin area to its water table, which equals $1: 69$, as well as domestic sewage inflow from surrounding tourist resorts. Consequently, in the last decade, severe blue-green algal blooms developed during summer seasons, among others. Additionally, for years, the reservoir has been subjected to pollution by industrial effluents containing heavy metals from a smelting plant.

Sediment samples were collected from three stations (T1-T3), which were evenly distributed from the dam towards the river inlet, to reflect various degree of contamination (Fig. 1). A standard Ekman grab sampler $(20 \times 20 \mathrm{~cm})$ was used to collect sediments (three samples per site). Each sample was a composite of 10 grab samples mixed with a hand-held power drill. Parallel subsamples for chemistry analyses and laboratory toxicity assessments were taken and stored at $4{ }^{\circ} \mathrm{C}$ in the dark.
Analytical methods

Prior to the chemical analysis, pore water was extracted from sediments by centrifugation at $4,500 \times g$ for $45 \mathrm{~min}$, then sediment samples were air-dried, homogenized, and passed through a $1 \mathrm{~mm}$ (pore size) sieve. Sediment physical and chemical characteristics included the following: (1) sediment particle size, (2) $\mathrm{pH}$ value, (3) electrical conductivity (EC), (4) organic carbon, (5) potassium, and (6) heavy metals $(\mathrm{Cd}, \mathrm{Cr}, \mathrm{Cu}, \mathrm{Mn}$, $\mathrm{Ni}, \mathrm{Pb}$, and $\mathrm{Zn}$ ). For metal analysis, the samples were digested with a mixture of $\mathrm{HNO}_{3}-\mathrm{HClO}_{4}$ in a microwave oven. Metal content was measured by atomic absorption spectroscopy using a doublebeam Philips UNICAM PU 9 100× spectrophotometer with deuterium background correction. Chemical parameters were determined in both dried sediments and pore waters, according to Polish standards.

Evaluation of sediment phytotoxcity was based on germination and seedling growth of the three vascular plants (sorghum Sorghum saccharatum,

Fig. 1 Location of Turawa dam reservoir and sampling sites

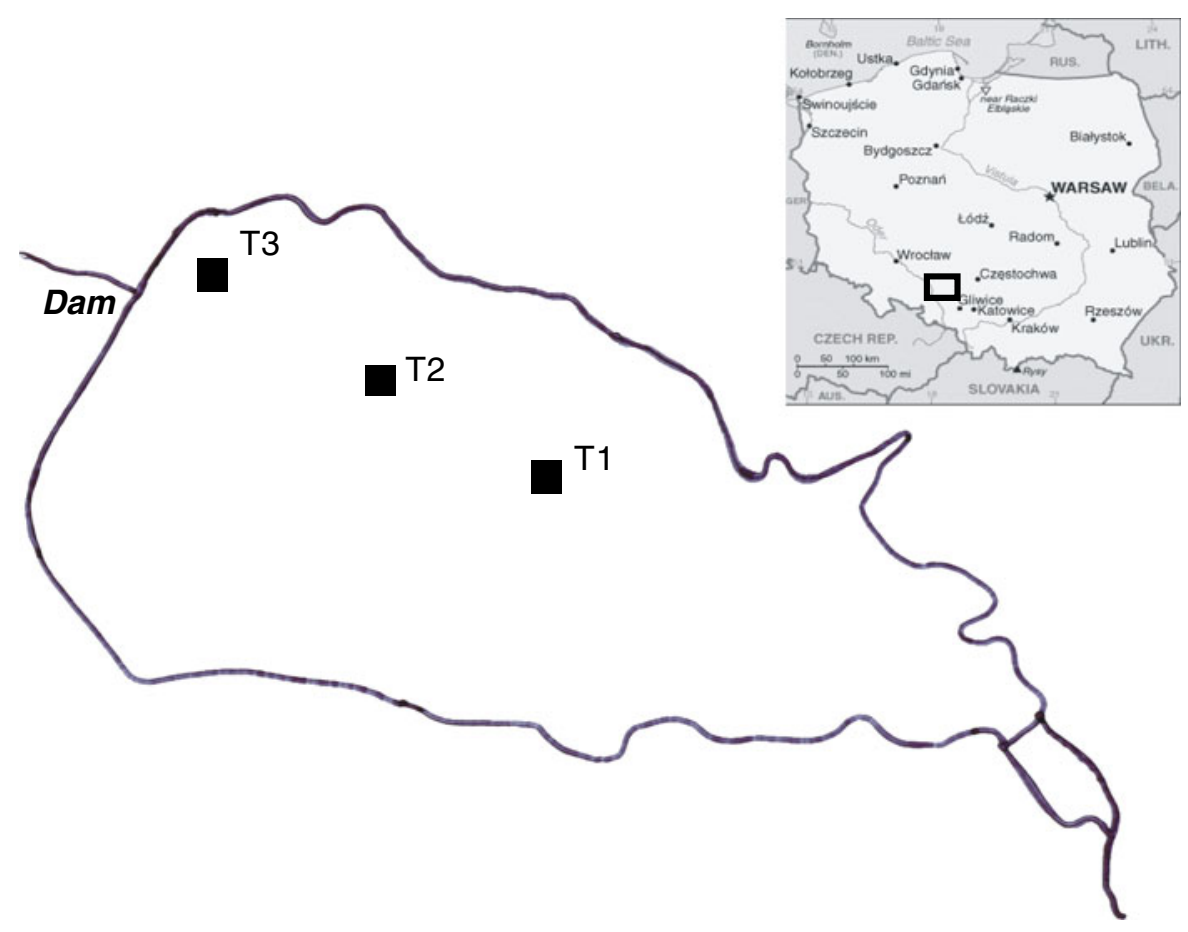


mustard Sinapis alba, and garden cress Lepidium sativum), using the Phytotoxkit microbiotest. Both end points of the toxicity analysis were combined in a germination index (GI), according to the equation: $\mathrm{GI}=\left(G_{\mathrm{s}} L_{\mathrm{s}}\right) /\left(G_{\mathrm{c}} L_{\mathrm{c}}\right)$ where $G_{\mathrm{s}}$ and $L_{\mathrm{s}}$ are seed germination (\%) and root elongation (mm) for the sample; $G_{\mathrm{s}}$ and $L_{\mathrm{c}}$ the corresponding control values. GI values within the range of 90 $110 \%$ were classified as "no effect". The Phytotoxkit microbiotest was performed on:

1. Whole sediments only after decantation of overlying water. In this case, tests were performed on sediments "as such", without any further sample preparation;

2. Solid phases of sediments, after centrifugation and drying;

3. Liquid phases of sediments (pore water).

Analyses of correlation coefficients between the physical-chemical parameters of sediments were conducted using Pearson Product Moment Correlation Coefficient. All results reported are the means of three replicates.

\section{Results and discussion}

\section{Properties of sediments}

As shown in Table 1, sampling sites slightly differed with respect to the type of sediments as deposition within the reservoir involved two physically and genetically distinct processes including silting and sand-up (Teisseyre 1983). Thus, sandy fraction made up the majority of sediment particles at site $\mathrm{T} 1(64 \%)$, the nearest to the river mouth. Whereas at sites T2 and T3 silt constituted the similar proportion in the sediment granulometric composition as sand, consequently black sapropelic mud occurred near the dam.
There was only a little difference in $\mathrm{pH}$ among the sampling sites. All $\mathrm{pH}$ values ranged from 6.04 to 6.36 indicating slightly acidic conditions. Mean values of electrical conductivity varied between 0.768 (T1) and $1.149 \mathrm{mS} \mathrm{cm}^{-1}$ (T3), revealing increased salinity of sediments collected near the dam. Generally, the conductivity as well as organic carbon and potassium contents gradually increased towards the dam. The amount of organic carbon ranged from $3.12 \%$ to $9.84 \%$ and potassium from 667 to $2,042 \mathrm{mg} \mathrm{kg}{ }^{-1}$ d.m. However, there were some differences in the accumulation ratio between sites of various granulometric composition. Organic carbon contents in muddy sediments of sites T2 and T3 were two to three times higher than in more sandy sediments of site T1. This tendency was not observed for potassium concentration. The content of potassium increased from site to site by approximately $40 \%$ (T1-T2) and 100\% (T2-T3). In spite of the high amount of potassium in sediments, its concentration in pore water was not above normal, ranging from 5.53 (T1) to $6.41 \mathrm{mg} \mathrm{dm}^{-3}$ (T3).

Sediment concentrations of heavy metals are summarized in Table 2. A similar pattern of sediment contamination was noted for the all analyzed heavy metals ( $\mathrm{Cd}, \mathrm{Cr}, \mathrm{Cu}, \mathrm{Mn}, \mathrm{Ni}, \mathrm{Pb}$, and $\mathrm{Zn}$ ). Their concentrations increased towards the dam. Among trace metals, $\mathrm{Cr}$ and $\mathrm{Ni}$, which ranged from 18.3 to $36.7 \mathrm{mg} \mathrm{kg}^{-1}$ d.m., revealed gradual increase as their content rise by approximately $40 \%$ from site to site. The average Mn concentration changed similarly at particular sampling sites, though the amount was much higher (326.0$940.3 \mathrm{mg} \mathrm{kg}{ }^{-1}$ d.m.) than that of $\mathrm{Cr}$ and $\mathrm{Ni}$. In turn, $\mathrm{Cd}, \mathrm{Zn}, \mathrm{Cu}$, and $\mathrm{Pb}$ showed an irregular increase pattern in the sediments with a significant leap between sites $\mathrm{T} 1$ and $\mathrm{T} 2$. $\mathrm{Cu}, \mathrm{Zn}$, and $\mathrm{Cd}$ concentrations, in particular, were over two times higher in silty/sandy sediments at sites T2 and

Table 1 Basic properties of sediment samples from Turawa reservoir

\begin{tabular}{|c|c|c|c|c|c|c|c|c|}
\hline \multirow[t]{2}{*}{ Sample } & \multicolumn{3}{|c|}{ Grain size (\%) } & \multirow[t]{2}{*}{$\mathrm{pH} \mathrm{H} \mathrm{H}_{2} \mathrm{O}$} & \multirow[t]{2}{*}{$\mathrm{pH} \mathrm{KCl}$} & \multirow[t]{2}{*}{$\mathrm{EC}\left(\mathrm{mS} \mathrm{cm}^{-1}\right)$} & \multirow{2}{*}{$\begin{array}{l}\text { Organic carbon } \\
(\%)\end{array}$} & \multirow{2}{*}{$\begin{array}{l}\text { Potassium } \\
\text { (mg kg}{ }^{-1} \text { d.m.) }\end{array}$} \\
\hline & Sand & Silt & Clay & & & & & \\
\hline $\mathrm{T} 1$ & 64 & 34 & 2 & 6.27 & 6.07 & $0.768(0.20)$ & $3.12(0.11)$ & $667(10)$ \\
\hline $\mathrm{T} 2$ & 45 & 54 & 1 & 6.21 & 6.04 & $0.991(0.11)$ & $7.32(0.10)$ & $1,090(11)$ \\
\hline $\mathrm{T} 3$ & 51 & 48 & 1 & 6.36 & 6.20 & $1.149(0.83)$ & $9.84(0.75)$ & $2,042(10)$ \\
\hline
\end{tabular}

Mean within the $95 \%$ confidence limits, SD in parentheses 
Table 2 Heavy metal content in samples from Turawa reservoir

\begin{tabular}{|c|c|c|c|c|c|c|c|}
\hline Sample & $\mathrm{Cd}$ & $\mathrm{Cr}$ & $\mathrm{Cu}$ & $\mathrm{Mn}$ & $\mathrm{Ni}$ & $\mathrm{Pb}$ & $\mathrm{Zn}$ \\
\hline \multicolumn{8}{|c|}{ Heavy metals in sediments ( $\mathrm{mg} \mathrm{kg}^{-1}$ d.m.) } \\
\hline $\mathrm{T} 1$ & $60.56(2.50)$ & $18.32(0.51)$ & $38.77(0.60)$ & $326.60(10.22)$ & $18.37(0.51)$ & $131.47(5.50)$ & $1,338.0(43.0)$ \\
\hline $\mathrm{T} 2$ & $168.00(6.00)$ & $25.95(1.14)$ & $80.00(8.97)$ & $540.50(13.00)$ & $26.00(1.53)$ & $215.75(4.09)$ & $2,920.6(27.0)$ \\
\hline $\mathrm{T} 3$ & $279.86(11.36)$ & $36.75(1.09)$ & $105.06(2.20)$ & $940.30(14.90)$ & $36.61(1.06)$ & $312.19(6.53)$ & $4,772.0(75.0)$ \\
\hline \multicolumn{8}{|c|}{ Heavy metals in pore water $\left(\mathrm{mg} \mathrm{dm}^{-3}\right)$} \\
\hline $\mathrm{T} 1-\mathrm{T} 3$ & $<0.001$ & $<0.008$ & $<0.002$ & $<0.004$ & $0.02-0.03$ & $<0.003-0.03$ & $0.044-0.097$ \\
\hline
\end{tabular}

Mean within the $95 \%$ confidence limits, SD in parentheses

T3 compared to sediments composed mainly of sand at site $\mathrm{T} 1$. The results of correlation analyses confirmed that heavy metal concentrations were significantly correlated with organic carbon content (Table 3). The correlation coefficients, which ranged between 0.5586 and 0.9521 , increased in the order $\mathrm{Ni}<\mathrm{Cr}<\mathrm{Cu}<\mathrm{Zn}<\mathrm{Pb}<\mathrm{Cd}$. In addition, $\mathrm{Cd}$ was significantly correlated with the EC value $(r=0.6970 ; p=0.001)$.

Generally, a similar pattern of sediment nutrient enrichment and heavy metal contamination was noted, as their amount increased towards the dam (from site $\mathrm{T} 1$ to $\mathrm{T} 3$ ). The results obtained were expected considering sediment characteristics of Turawa reservoir. It has been observed (Soares et al. 1999) that heavy metals accumulate more extensively in the thinner fractions of sediments and, therefore, they are mainly linked to silt and clay. Variability of the amount of heavy metals contained in this grain fraction may be caused by the variety of clay minerals with different cation exchange capacity (Wardas et al. 1996). Heavy metal uptake by the thin fraction of sediments is also clearly related to its organic matter content. The presence of high organic matter content in sediments is shown to increase the absorbabilities of heavy metals (Lin and Chen 1998). Correlations between grain size fraction and nutrient content, and the significant accumulation of potassium in sediments of less than $0.500 \mathrm{~mm}$ grain size, have also been presented, mainly in terms of water erosion and a decline in soil yield potential (Bertol et al. 2007).

In contrast to the solid sediments, the trace metal concentrations in pore waters were much lower. Concentrations of the majority of the analyzed elements $(\mathrm{Cd}, \mathrm{Cr}, \mathrm{Cu}, \mathrm{Ni}$, and $\mathrm{Mn})$ remained constant, at a level from $<0.001 \mathrm{mg} \mathrm{dm}^{-3}$ for $\mathrm{Cd}$ to $0.03 \mathrm{mg} \mathrm{dm}^{-3}$ for $\mathrm{Ni}$. The concentrations of $\mathrm{Zn}$ and $\mathrm{Pb}$ vary among the particular sites, however, with decreasing tendency towards the dam. Such a substantial difference between pore water and solid sediments indicates the existence of some specific conditions that are favorable for binding abilities and sorption properties of the analyzed sediments.

\section{Sediment phytotoxicity}

For the pore waters the majority of GI values were not statistically different from the controls, with the exception of clear growth stimulation of S. saccharatum at site T1 (Fig. 2). Thus, the results of phytotoxicity tests were consistent with the chemical data.

For sediments, in turn, GI values showed diversified effects, which ranged from growth inhibition to growth stimulation. Moreover, $72 \mathrm{~h}$ exposure to solid phases of sediments gave, as a general rule, opposite results for S. saccharatum and L. sativum

Table 3 Correlation analysis for heavy metals, potassium, and organic carbon content, and EC values

\begin{tabular}{lllllllll}
\hline Parameters & $\mathrm{Cd}$ & $\mathrm{Cr}$ & $\mathrm{Cu}$ & $\mathrm{Mn}$ & $\mathrm{Ni}$ & $\mathrm{Pb}$ & $\mathrm{Zn}$ & $\mathrm{K}$ \\
\hline Organic & 0.9521, & 0.6430, & 0.6551, & 0.5628, & 0.5586, & 0.9224, & 0.8762, & 0.9281, \\
carbon & $p=0.001$ & $p=0.001$ & $p=0.001$ & $p=0.001$ & $p=0.001$ & $p=0.001$ & $p=0.001$ & $p=0.001$ \\
$\mathrm{EC}$ & 0.6970, & 0.5741, & 0.5930, & 0.5651, & 0.6234, & 0.6299, & 0.6702, & 0.4927, \\
& $p=0.001$ & $p=0.051$ & $p=0.050$ & $p=0.056$ & $p=0.033$ & $p=0.026$ & $p=0.014$ & $p=0.037$ \\
\hline
\end{tabular}


Fig. 2 Germination index values ( $\%$ of control, mean, and standard deviation) and effects of plant reaction in pore waters

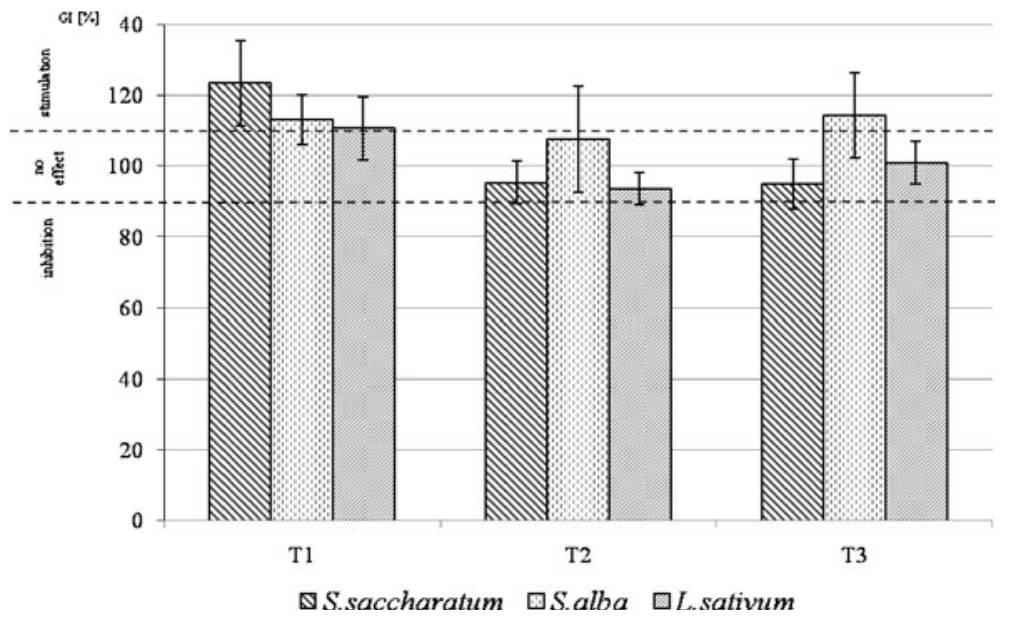

as compared to the tests with whole sediments (Fig. 3). Tests with heavy metal-rich solid phases of sediments revealed a significant stimulation, particularly for the dicotyledons $S$. alba and $L$. sativum. The stimulating effect on L. sativum increased gradually from site to site (T1-T3). The most pronounced root growth, exceeding the controls over $137 \%$, appeared in sediments T3. An even higher beneficial effect on plant development was observed for S. alba. Mean GI values ranged between $176 \%$ and $205 \%$, revealing rather small differences among the particular sites. Enhanced growth of $S$. saccharatum was observed only at site T3 (GI 120\%), which has the highest concentrations of trace elements, $\mathrm{K}$, and organic carbon in sediments. For sites T1 and T2, a slight inhibitory effect was found with mean GI values of $83.6 \%$ and $85.0 \%$, respectively. However, according to Emino and Warman (2004), GI values above $80 \%$ suggest no phytotoxicity.

There are many factors that might have an impact on this plant response. Though numerous
Fig. 3 Germination index values ( $\%$ of control, mean, and standard deviation) and effects of plant reaction in solid phases (T1-T3) and whole sediments $\left(T 1^{*}-T 3^{*}\right)$

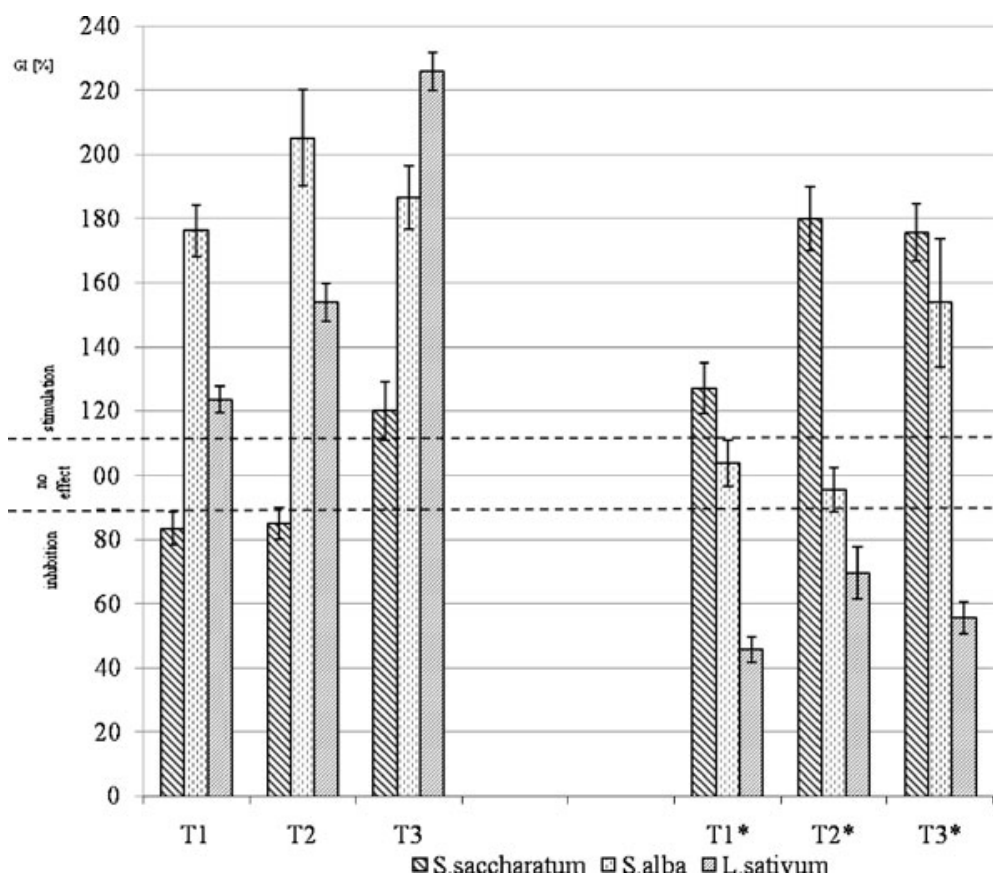


authors have shown the inhibitory effects of heavy metals on growth and development of a wide variety of plants (Obroucheva et al. 1998; Valerio et al. 2007), there are also studies which report adverse effects on root growth under various conditions. Since elements with similar physicochemical properties may replace one another in enzymatic pathways and receptor proteins, they compete for absorption, transport, and accumulation. Fargašova (1999) reported that $\mathrm{Mo}, \mathrm{Cu}$, and $\mathrm{Mn}$ had strong antagonistic effect to $\mathrm{Ni}$ and in combination with this metal a significant stimulatory effect on $S$. alba seedlings was observed in hydroponic cultivation. It is also well established from many studies that the accumulation mechanisms of heavy metals in sediments imply the existence of four main speciation categories, which have a different behavior regarding remobilization. These fractions include metals adsorbed and bound to: (1) carbonate phases, (2) reducible phases, (3) organic matter and sulfides, as well as (4) detrital or residual metals (van Ryssen et al. 1999). Therefore, possible explanations for the lack of toxicity in solid phases of sediments in this study are: (1) the presence of heavy metals in a very stable and insoluble form or (2) the binding of particular metals to cation exchange sites with a consequent reduced bioavailability. In addition, higher amount of nutrients adsorbed on organic matter-rich sediments might conceal the inhibitory impact of phytotoxic contaminants in sediments and hence give a false negative assessment. A similar effect was observed by Gong et al. (2001) during soil studies.

Among macronutrients essential to plant life, in most terrestrial plants $\mathrm{K}^{+}$is the major cationic inorganic nutrient. Potassium is needed for metabolic reactions as $\mathrm{K}^{+}$activates a multitude of enzymes and generates turgor, thus it provides water homeostasis and drives cell expansion and plant growth (Maathuis 2009). Sediments of Turawa reservoir contained high amount of potassium and it is likely that they are also rich in other nutrients, such as phosphorus and nitrogen. Such a significant nutrient content might result in root growth stimulation.

By contrast, tests with whole fresh sediments showed adverse effects. It should be noted, that in this case seeds were exposed to sediments of lower $\mathrm{pH}$ value (5.85). As each plant responded differently to contaminated sediments, GI values showed a wide range of effects, from the growth inhibition of L. sativum to the growth stimulation of $S$. saccharatum. In spite of increasing metal contamination in the sediments (from site T1 to T3), all the analyzed samples caused an inhibitory effect on L. sativum, particularly sediments T1. Low GI value obtained for this site resulted mainly from a suppressed root elongation. The growth of the primary roots was inhibited by approximately $45 \%$ on the third day. In turn, in sediments T2 and T3 low GI values resulted from both suppressed root elongation and reduced seed germination. In comparison to sediments $\mathrm{T} 1$, a weaker inhibition of root growth was observed, yet the seed germination decreased much more markedly (up to $30 \%$ ). For S. alba, sediments from sites $\mathrm{T} 1$ and $\mathrm{T} 2$ did not exert any effects in comparison with the controls, while sediments from site T3 revealed stimulation. All sediment samples had a beneficial impact on $S$. saccharatum growth. The stimulating strength was, however, significantly higher (by 50\%) in tests with sediments rich in organic carbon and potassium from sites $\mathrm{T} 2$ and $\mathrm{T} 3$.

Though sediments were not classified as acidic, a high substrate acidity might influence trace element remobilization (Guevara-Riba et al. 2004) as well as limited nutrient availability (Kajak 1995). Thus, the suppressed development of L. sativum and, to some degree, also of S.alba can be explained by the gradual accumulation of heavy metals up to a threshold concentration at which inhibition starts.

In conclusion, ecological risk assessment of contaminated sediments is often complicated by numerous factors affecting bioavailability, species' sensitivity, and contaminant interactions, ranging from additive, antagonistic to synergistic ones. This study illustrates the importance of sediment characteristics, such as grain-size distribution, $\mathrm{pH}$, organic matter, and nutrient content in reducing the growth impact of heavy metals on vascular plants. It also demonstrates the complex interactions that may occur in the real environment. In terms of phytotoxicity, higher amount of nutrients adsorbed on organic matter-rich sediments may conceal, under specific conditions, the 
inhibitory impact of pollutants on plants. Thus, beneficial effects on the plants may overrun harmful ones and lead to a biased hazard interpretation. On the other hand, a significant growth stimulation is indicative of a nutrient load and its potential resuspension from sediments to overlying water, which might accelerate the reservoir eutrophication. The monocotyledons ( $S$. saccharatum) and dicotyledons (L. sativum) plant species responded differently to contaminated sediments, in both analyzed variants, reflecting their own specific physiological mechanisms for reaction and adaptation to stress factors. The data obtained in this study clearly show the potential of the Phytotoxkit microbiotest with three different plant test species, each with their own sensitivity to toxicants, for the detection of hazards threatening the aquatic ecosystem integrity.

Open Access This article is distributed under the terms of the Creative Commons Attribution Noncommercial License which permits any noncommercial use, distribution, and reproduction in any medium, provided the original author(s) and source are credited.

\section{References}

Beltrami, M., Rossi, D., \& Baudo, R. (1999). Phytotoxicity assessment of Lake Orta sediments. Aquatic Ecosystem Health Management, 2, 391-401.

Bertol, I., Engel, F. L., Mafra, A. L., Bertol, O. J., \& Ritter, S. R. (2007). Phosphorus, potassium and organic carbon concentrations in runoff water and sediments under different soil tillage systems during soybean growth. Soil Tillage Research, 94, 142-150.

Chapman, P. M. (1990). The sediment quality triad approach to determining pollution-induced degradation. Science of the Total Environment, 97(98), 815-825.

Chen, Y. X., Zhu, G. W., Tian, G. M., Zhou, G. D., Luo, Y. M., \& Wu, S. C. (2002). Phytotoxicity of dredge sediment from urban canal and land application. Environmental Pollution, 117, 233-241.

Cheung, Y. H., Neller, A., Chu, K. H., Tam, N. F. Y., Wong, Y. S., \& Wong, M. H. (1997). Assessment of sediment toxicity using different trophic organisms. Archives of Environmental Contamination and Toxicology, 32, 260-267.

Chung, M. K., Hu, R., Wang, M. H., \& Chung, K. C. (2007). Comparative toxicity of hydrophobic contaminants to microalgae and higher plants. Ecotoxicology, 16, 393402.

Devesa-Rey, R., Moldes, A. B., \& Dias-Fierros, F. (2008). Toxicity of Anllóns River sediment extracts using Microtox and the Zucconi Phytotoxicity Test. Bulletin of Environmental Contamination and Toxicology, 80, 225-230.

Emino, E. R., \& Warman, P. R. (2004). Biological assay for compost quality. Compost Science \& Utilization, 12(4), 342-348.

Fargašova, A. (1999). Determination of metal interactions on root growth of Sinapis alba seedlings. Biologia Plantarum, 42(4), 637-640.

Filidei, S., Masciandaro, G., \& Ceccanti, B. (2003). Anaerobic digestion of olive oil mill effluents: Evaluation of wastewater organic load and phytotoxicity reduction. Water, Air and Soil Pollution, 145, 79-94.

Garcia-Lorenzo, M. L., Martinez-Sánchez, M. J., PerezSirvent, C., \& Molina, J. (2009). Ecotoxicological evaluation for the screening of areas polluted by mining activities. Ecotoxicology, 18, 1077-1086.

Gong, P., Wilke, B. M., Strozzi, E., \& Fleischmann, S. (2001). Evaluation and refinement of a continuous seed germination and early seedling growth test for the use in the ecotoxicological assessment of soils. Chemosphere, 44, 491-500.

Guevara-Riba, A., Sahuquillo, A., Rubio, R., \& Rauret, G. (2004). Assessment of metal mobility in dredged harbour sediments from Barcelona, Spain. Science of the Total Environment, 321, 241-255.

Günter, P., \& Pestemer, W. (1990). Risk assessment for selected xenobiotics by bioassay methods with higher plants. Environmental Management, 14, 381-388.

Kajak, Z. (1995). Eutrophication of lowland reservoirs. In M. Zalewski (Ed.), Biological processes in the conservation and restoration of lowland reservoirs (pp. 3342). Łódź: PIOŚ, (in Polish).

Lin, J. G., \& Chen, S. Y. (1998). The relationship between adsorption of heavy metal and organic matter in river sediments. Environment International, 24(3), 345352.

Maathuis, F. J. M. (2009). Physiological functions of mineral macronutrients. Current Opinion Plant Biology, 12, 250-258.

McCauley, D. J., De Graeve, G. M., \& Linton, T. K. (2000). Sediment quality guidelines and assessment: Overview and research needs. Environmental Science \& Policy, 3, 133-144.

Mohan, B. S., \& Hosetti, B. B. (1999). Aquatic plants for toxicity assessment. Environmental Research Section A, 81, 259-274.

Nakamura, T., Adu-Gyamfi, J. J., Yamamoto, A., Ishikawa, S., Nakano, H., \& Ito, O. (2002). Varietal differences in root growth as related to nitrogen uptake by sorghum plants in low-nitrogen environment. Plant and Soil, 245, 17-24.

Obroucheva, N. V., Bystrova, E. I., Ivanov, V. B., Antipova, O. V., \& Seregin, I. V. (1998). Root growth responses to lead in young maize seedlings. Plant and Soil, 200, 55-61.

Persoone, G., Janssen, C., \& De Coen, W. (Eds.) (2000). New microbiotests for routine toxicity screening and biomonitoring. New York: Kluwer Academic.

Phytotoxkit (2004). Seed germination and early growth microbiotest with higher plants. Standard operational procedure. Nazareth: MicroBioTests Inc. 
Salomons, W., De Rooij, N. M., Kerdijk, H., \& Bril, J. (1987). Sediments as a source for contaminants. Hydrobiologia, 13, 30-38.

Soares, H. M. V. M., Boaventura, R. A. R., Machado, A. A. S. C., \& Esteves da Silva, J. C. G. (1999). Sediments as monitors of heavy metal contamination in the Ave river basin (Portugal): Multivariate analysis of data. Environmental Pollution, 105, 311-323.

Teisseyre, A. K. (1983). Bottom sediments of Turawskie Lake: A geological study. Geologia Sudetica, 18(1), 21-60 (in Polish).

Valerio, M. E., Garcia, J. F., \& Peinado, F. M. (2007). Determination of phytotoxicity of soluble elements in soils, based on a bioassay with lettuce (Lactuca sativa L.). Science of the Total Environment, 378, 63-66.

van Ryssen, R., Leermakers, M., \& Baeyens, W. (1999). The mobilization potential of trace metals in aquatic sediments as tool for sediment quality classification. Environmental Science \& Policy, 2, 75-86.
Vasseur, L., Fortin, M. J., \& Cyr, J. (1998). Clover and cress as indicator species of impacts from limed sewage sludge and landfill wastewater land application. Science of the Total Environment, 217, 231-239.

Wang, W. (1991). Literature review on higher plants for toxicity testing. Water, Air and Soil Pollution, 59, 381-400.

Wang, W., \& Williams, J. M. (1988). Screening and biomonitoring of industrial effluents using phytotoxicity tests. Environmental Toxicology and Chemistry, 7, 645-652.

Wardas, M., Budek, L., \& Helios-Rybicka, E. (1996). Variability of heavy metals content in bottom sediments of the Wilga River, a tributary of the Vistula River (Krakow area, Poland). Applied Geochemistry, 11, 197-202.

Wierzbicka, M. (1994). Resumption of mitotic activity in Allium cepa root tips during treatment with lead salt. Environmental and Experimental Botany, 34, 173180 . 